Wojciech Mądry (Instytut Slawistyki Polskiej Akademii Nauk) dr, wojciechmadry58@o2.pl

\title{
Spuścizna jako źródło do badań nad biografią i działalnością naukową historyka - badacza dziejów Słowiańszczyzny Andrzeja Wędzkiego (1927-2017)
}

Dokonując analizy sylwetki żyjącego niegdyś człowieka, sięgamy do różnych kategorii źródeł mogących udzielić nam mniej lub bardziej szczegółowych informacji niezbędnych do jej sporządzenia. Im bogatszym zasobem źródeł będziemy dysponować, tym bardziej utwierdzimy się $\mathrm{w}$ przeświadczeniu, że dzięki niemu mamy możliwość przeprowadzenia szczegółowej analizy życia i działalności badanej postaci, wydobycia na światło dzienne wielu nieznanych lub fałszywie dotąd interpretowanych faktów z tego obszaru, a w efekcie niejednokrotnie stworzenia na nowo biografii badanego człowieka. Szczególną rolę, umożliwiającą bliższe poznanie zmarłej osoby, odgrywają pozostawione przez nią archiwa osobiste, czyli spuścizny. Zwłaszcza w odniesieniu do badań prowadzonych nad działalnością ludzi związanych z nauką i kulturą są one bezcennym źródłem historycznym. Historykom i biografom ukazują one nie tylko obraz związany z pracą zawodową badanej osoby, lecz także jej życie prywatne i rodzinne. Dzięki tym materiałom możemy otrzymać dużo szerszy i bogatszy portret interesującego nas człowieka. Często jednak tak szeroko zakrojone badania biograficzne napotykają na znaczne trudności, niekiedy nawet uniemożliwiające ich przeprowadzenie, ponieważ zgromadzona na przestrzeni życia spuścizna zawierająca dokumenty osobiste, rodzinne oraz korespondencję, a także nieopublikowane prace naukowo-badawcze często $\mathrm{z}$ wielu powodów ulega rozproszeniu. Ma to miejsce zwłaszcza w odniesieniu do spuścizn lub ich części pochodzących z okresu przed drugą wojną światową i na zawsze utraconych w wyniku działań wojennych. Wśród innych przyczyn braku dostępu do danej spuścizny możemy wyróżnić jej nieuregulowany stan prawny po śmierci twórcy. Często też jest ona dzielona i częściowo tylko przekazywana przez spadko- 
bierców do różnych zbiorów archiwalnych i bibliotecznych. Zatem nie zawsze badacz ma możliwość pełnego dostępu do spuścizny interesującej go postaci. Spuścizna, którą pragnę tutaj bliżej przedstawić, z uwagi na swoje bogactwo i wszechstronność pozwala nam zarówno poznać biografię jej twórcy, jak też dzieje jego rodziny na przestrzeni niemal dwóch ostatnich stuleci. Pozostawił ją zmarły w Poznaniu 13 grudnia 2017 r., kilka dni po swoich dziewięćdziesiątych urodzinach, prof. Andrzej Wędzki. Urodził się 14 listopada 1927 r. w Lesznie, jego rodzice byli nauczycielami w tamtejszej Państwowej Szkole Handlowej, a od 1 września 1937 r. - po reorganizacji tej szkoły na Koedukacyjne Gimnazjum Kupieckie - ojciec otrzymał stanowisko dyrektora, które zajmował aż do wybuchu wojny. Matka pochodziła z terenu dawnej Galicji, a ojciec z leżącego w jej pobliżu, ale już na terenie zaboru rosyjskiego Miechowa. Pod koniec sierpnia 1939 r. Wędzki waz z matką i młodszą siostrą Ireną opuścił Leszno w obawie przed oczekiwaną agresją Niemiec na Polskę. Ostatecznie po zakończeniu tułaczki na terenach obecnej środkowej Polski, w tym także po pobojowisku bitwy nad Bzurą, połączona szczęśliwie rodzina lata okupacji spędziła na terenie utworzonego przez Niemców Generalnego Gubernatorstwa, przebywając początkowo - od jesieni 1939 r. do czerwca 1940 r. w Krakowie, a następnie, aż do wyzwolenia w 1945 r., w Miechowie, gdzie Andrzej Wędzki na tajnych kompletach zdobywał wiedzę w zakresie szkoły średniej. Po zakończeniu działań wojennych powrócił on wraz z rodziną do Leszna, po czym w 1946 r. rozpoczął studia na kierunku ekonomia, a później także prawo na Wydziale Prawno-Ekonomicznym Uniwersytetu Poznańskiego. Ukończył je w roku 1952 i niebawem, w 1953 r., został zatrudniony przez założyciela Instytutu Zachodniego prof. Zygmunta Wojciechowskiego w Redakcji Stownika starożytności słowiańskich (SSS), początkowo związanej z Instytutem Zachodnim, a od 1955 r. aż do ukazania się ostatniego tomu tego wydawnictwa w 1996 r. z Zakładem Słowianoznawstwa PAN, obecnym Instytutem Slawistyki PAN. Z miejscem tym związany był się przez całe życie zawodowe, przechodząc przez wszystkie szczeble kariery, począwszy od pomocnika sekretarza, aż do długoletniego (w latach 19842006) kierownika Zakładu. Jak sam z dumą podkreślał, był on ostatnim, najmłodszym uczniem prof. Zygmunta Wojciechowskiego. Niemal przez cały czas wydawania SSS poza samodzielnym opracowywaniem licznych haseł do wszystkich tomów tego wydawnictwa, spoczywała na nim także odpowiedzialność za ich dobór, a także pilnowanie, by autorzy na czas wywiązywali się ze swoich zobowiązań wobec Redakcji, a Redakcja regulowała bez opóźnień swoje zobowiązania finansowe wobec autorów ${ }^{1}$. Oprócz kilkuset haseł

${ }^{1}$ Stownik starożytności stowińskich. Encyklopedyczny zarys kultury Stowian od czasów najdawniejszych, t. 1-8, pod red. A. Gąsiorowskiego, W. Kowalenki, G. Labudy, T. Lehr-Spławińskiego, A. Wędzkiego, Wrocław 1961-1996. 


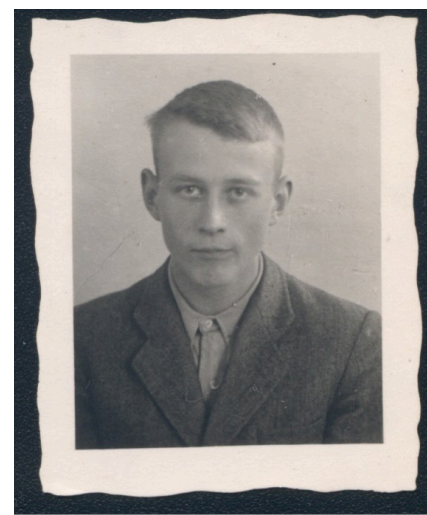

Fotografia Andrzeja Wędzkiego z okresu studiów ok. 1950 r. Zdjęcie ze zbiorów Archiwum PAN w Warszawie Oddział w Poznaniu.

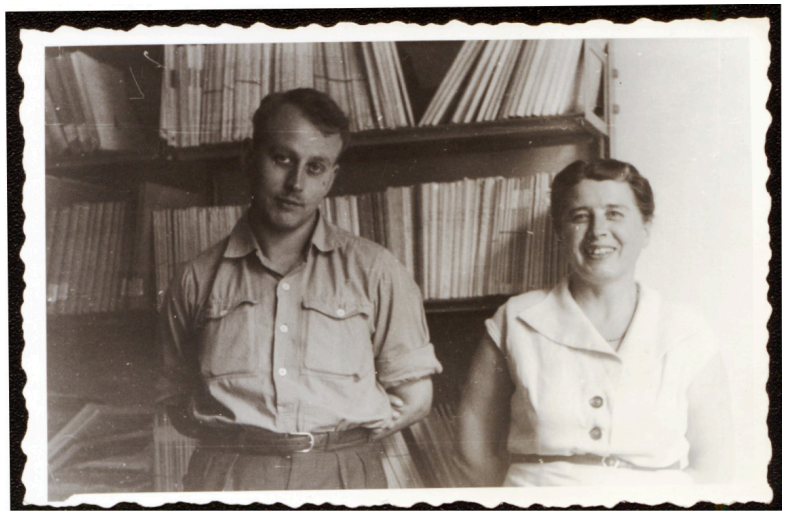

Andrzej Wędzki krótko po rozpoczęciu pracy w Redakcji Słownika starożytności stowiańskich, w siedzibie Redakcji Słownika przy ul. Chełmońskiego w Poznaniu. Zdjęcie wykonano ok. 1954-1955 r. Z prawej strony stoi pracownica Sekretariatu Stownika pani Jadwiga Morawska-Rybakowa. Zdjęcie ze zbiorów Archiwum PAN w Warszawie Oddział w Poznaniu.

do wszystkich ośmiu tomów SSS ma on także w dorobku ponad 270 różnego rodzaju publikacji w formie monografii i artykułów oraz innych wydawnictw encyklopedycznych z dziedziny historii, dziejów osadnictwa, regionalistyki, archeologii i numizmatyki ${ }^{2}$. W trakcie pracy nad SSS gromadził on też księgozbiór do biblioteki redakcyjnej, która z biegiem lat rozrosła się z niewielkiego podręcznego księgozbioru do liczącej ok. czterdzieści tys. woluminów jedynej w Polsce biblioteki posiadającej wiele cennych pozycji z zakresu wczesnośredniowiecznej historii Słowian, a także archeologii oraz osadnictwa na terenach środkowej Europy. Wykorzystując każdą nadarzającą się okazję, odnajdywał też dojścia do składnic, w których niszczały wówczas stosy książek zwożonych z poniemieckich instytucji, zwłaszcza na Śląsku, m.in. w Bytomiu czy Katowicach nazywanych wówczas Stalinogrodem, skąd w plecaku zwoził kilogramami książki do tworzonej przy Redakcji SSS biblioteki. Dzięki jego kontaktom z ówczesną dyrekcją Archiwum Państwowego w Poznaniu Redakcja SSS otrzymała także do powstającej wówczas biblioteki wiele cennych pozycji dotyczących zwłaszcza onomastyki słowiańskiej, pochodzących z księgozbioru ks. Stanisława Dołęgi-Kozierowskiego, przekazanego przez niego w drodze testamentu Archiwum Państwowemu w Poznaniu ${ }^{3}$.

2 Pełna bibliografia prac Andrzeja Wędzkiego została przedstawiona w pracy: A. Wędzki, Przechadzki po Wielkopolsce, Poznań 2007, s. 11-35.

${ }^{3}$ Z okazji przypadających w 2007 r. osiemdziesiątych urodzin prof. Wędzkiego ukazały się dwa artykuły autorstwa Ryszarda Grzesika. W pierwszym z nich omówił on kształtowanie się i rozwój zainteresowań badawczych Wędzkiego, natomiast w drugim przedstawił jego za- 


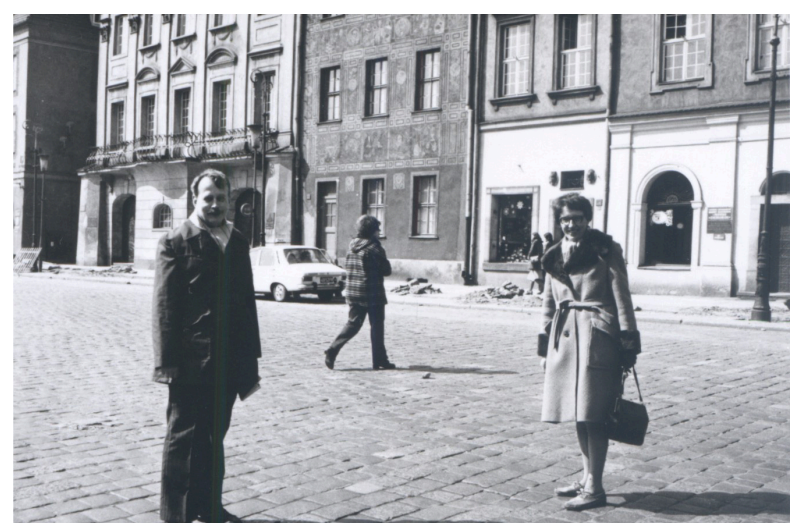

Andrzej Wędzki wraz z małżonką na Starym Rynku w Poznaniu przed Pałacem Działyńskich w 1975 r. Zdjęcie ze zbiorów Archiwum PAN w Warszawie Oddział w Poznaniu.

Po dokładniejszym zapoznaniu się ze spuścizną pozostawioną przez Wędzkiego nietrudno dostrzec, że była ona systematycznie tworzona na przestrzeni wielu dziesięcioleci, aż do schyłku życia jej autora. Wszystkie materiały, a w szczególności te, które zamierzał on przekazać do archiwum, pozostawił on tematycznie posegregowane i umieszczone $\mathrm{w}$ oddzielnych, opisanych teczkach. W podobny sposób skatalogował on też swoją bogatą kolekcję numizmatyczną liczącą ok. dziewięć tys. monet i medali oraz liczne banknoty, w tym szczególnie te, które były emitowane w różnych okresach i spełniały funkcję pieniądza zastępczego. Kolekcja ta stanowi wydzieloną część spuścizny, która w drodze testamentu została przekazana na własność Bibliotece Kórnickiej. Chcąc poznać pełen zakres spuścizny naukowej Wędzkiego, zgodnie z jego wolą wydzielonej spośród materiałów przekazanych do poznańskiego Oddziału Archiwum PAN, to obok kolekcji numizmatycznej nie można pominąć liczącego niemal dziesięć tys. woluminów bogatego księgozbioru o tematyce osadniczej, archeologicznej, numizmatycznej oraz biograficznej wraz z licznymi wydawnictwami źródłowymi, a także bogatym zbiorem map zwłaszcza dawnych sztabowych, darowanego zgodnie z jego ostatnią wolą Instytutowi Slawistyki PAN. Pod koniec swojego życia Wędzki zdążył przekazać już niewielką część swojej spuścizny do poznańskiego Oddziału Archiwum PAN. Można zatem postawić pytanie: czy mogło być jego zamiarem, aby po śmierci materiały zawarte w spuściźnie posłużyły przyszłym badaczom do zbudowania jego wizerunku według kryteriów świadomie narzuconych przez niego za życia? Czy może pragnął on za pośrednictwem dziejów swojej rodziny podkreślić wpływ, jaki wywar-

interesowania regionalistyką na przykładzie badań nad osadnictwem ziemi konińskiej. Zob.: R. Grzesik, Profesor Andrzej Wędzki jako archeolog i slawista w 80-lecie urodzin, "Slavia Antiqua” 2007, t. 48, s. 285-316; tegoż, Profesor Andrzej Wędzki jako badacz Ziemi Konińskiej, „Rocznik Koniński" 2007, t. 16, s. 347-350. 
Andrzej Wędzki w dniu swoich osiemdziesiątych urodzin 14 listopada 2007 r. przyjmuje życzenia od swoich byłych współpracowników. Na zdjęciu pierwsza z lewej jego żona Anna Niesiołowska-Wędzka. Zdjęcie ze zbiorów własnych autora.

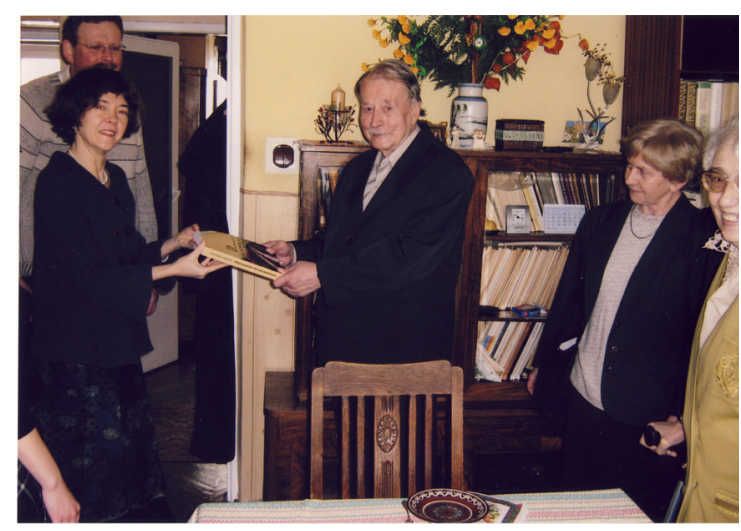

ły na życiu poszczególnych jednostek burzliwe wydarzenia rozgrywające się na terenach ziem polskich $w$ XX w.? Na to pytanie niestety nie znajdziemy jednoznacznej odpowiedzi. Jednak próba jej znalezienia jeszcze bardziej skłania nas do bliższego zapoznania się zarówno z pozostawionym przez niego materiałem wchodzącym w skład spuścizny przekazanej poznańskiemu Oddziałowi Archiwum PAN, jak i z postacią jego twórcy. Podobnie jak w wielu innych spuściznach profesorskich, duża jej część składa się rękopisów i maszynopisów prac naukowych zarówno tych, które doczekały się publikacji, jak i niepublikowanych. Wszystkie one wskazują na zakres oraz problematykę badań prowadzonych przez Wędzkiego w kolejnych etapach jego życia.

Szczególną uwagę przykuwa jednak pozostała część, wyraźnie wskazująca na zamiłowania jej twórcy do kolekcjonowania. W jej skład wchodzi szereg różnego rodzaju materiałów świadczących zarówno o jego pasji kolekcjonowania przedmiotów materialnych, jak też wewnętrznej potrzebie do utrwalenia w czasie owej „ulotnej chwili”, na którą składają się: rodzinne relacje, wspomnienia, relacje z podróży, tablice genealogiczne przedstawiające rodzinne koligacje oraz tysiące zdjęć wykonanych własnoręcznie aparatem fotograficznym „Exa”. W miarę zagłębiania się w tę spuściznę odnosi się wrażenie, jakoby w zamierzeniu jej twórcy miała ona w przyszłości zostać wykorzystana w charakterze źródła do prowadzenia badań naukowych. Warto zatem przyjrzeć się jej nieco dokładniej z uwagi na bogactwo i różnorodność, a także spojrzeć $\mathrm{z}$ nieco bliższego dystansu na twórcę tych materiałów oraz okoliczności i czasy, w jakich powstawały. Pragnę jednak podkreślić, że z uwagi na fakt, że od śmierci jej twórcy upłynęło zaledwie kilka miesięcy, nie została ona jeszcze $w$ pełni opracowana. Skoncentruję jednak swoją uwagę na kilku jej fragmentach, stanowiących ciekawy materiał nie tylko do poznania biografii Wędzkiego, lecz także będących ciekawym przyczynkiem do najnowszej historii naszego kraju. 
Pierwszy z nich stanowi zawartość dwóch niczym niewyróżniających się szarych brulionów formatu A-5, leżących za życia Wędzkiego na biurku w jego mieszkaniu ${ }^{4}$. Zawierają one ciekawy materiał związany zarówno z jego osobą, jak też z jego bliską i dalszą rodziną. Nie mają one formy pamiętników. Są to raczej niepowiązane $z$ sobą luźne notatki sporządzane po latach od opisywanych przez nie wydarzeń. Składają się one z krótkich informacji zapisanych odręcznie $\mathrm{w}$ formie szkiców zarówno o charakterze własnych wspomnień, jak i zasłyszanych od różnych osób opowieści związanych z dziejami rodzinnymi z okresu ostatnich dwóch stuleci. Niektóre z nich są opatrzone datami ich sporządzenia oraz imionami osób, od których zostały uzyskane $\mathrm{w}$ trakcie rozmowy. Materiał zawarty $\mathrm{w}$ tych brulionach opisuje m.in. okres dojrzewania i krystalizowania się zainteresowań badawczych Wędzkiego jako młodego człowieka dorastającego beztrosko w końcu dwudziestolecia międzywojennego, następnie rzuconego wraz z najbliższą rodziną $\mathrm{w}$ wir wydarzeń lat wojny i okupacji, a po jej zakończeniu wkraczającego w dorosłe życie jako badacz i pracownik naukowy w trudnym okresie pierwszych lat powojennej odbudowy kraju, wraz $\mathrm{z}$ nachalnie wprowadzaną $\mathrm{w}$ tym czasie przez władze ideologią komunizmu. Tym bardziej warto przyjrzeć się nieco bliżej ich zawartości ${ }^{5}$. W pierwszym z tych brulionów natrafiamy na liczne, odręcznie napisane retrospektywne wspomnienia, pochodzące $z$ lat sześćdziesiątych i siedemdziesiątych XX w. Niektóre z nich opatrzone są datami i sięgają wydarzeń, których Wędzki był świadkiem lub uczestnikiem w okresie międzywojennym i w latach okupacji. Szczególną uwagę zwracają umieszczone $\mathrm{w}$ tym zeszycie liczne luźne, pożółkłe kartki z notatkami stanowiącymi relację z wojennej tułaczki we wrześniu 1939 r. Na jednej z nich znajdujemy rozpisany dzień po dniu obraz ostatniej dekady sierpnia 1939 r., jaki na zawsze pozostał w pamięci Wędzkiego, do którego często powracał po latach $\mathrm{w}$ trakcie prowadzonych rozmów. Rozpoczyna się on opisem rychłego powrotu z wakacji spędzanych w Jordanowie do rodzinnego Leszna, w którym jego ojciec, dyrektor Szkoły Handlowej, musiał wrócić w związku ze zbliżającą się niebawem - 24 sierpnia - mobilizacją ${ }^{6}$. Dalej natrafiamy na opisy go-

${ }^{4}$ Autor artykułu przez wiele lat utrzymywał prywatne kontakty z Andrzejem Wędzkim. Przekazywał także materiały archiwalne należące do Profesora - zarówno za jego życia, jak i po śmierci - Oddziałowi Archiwum PAN w Poznaniu.

${ }^{5}$ Materiały wchodzące w skład spuścizny prof. Wędzkiego nie zostały jeszcze opracowane, w związku z tym obecnie nie posiadają numerów inwentarza.

${ }^{6}$ Gdy odwiedzałem prof. Wędzkiego pod koniec życia w jego mieszkaniu, w pewien pogodny letni dzień 2017 r. w trakcie rozmowy zadał mi pytanie: Czy wiem jaki mamy dzisiaj dzień? Odpowiedziałem, że 24 sierpnia. Wówczas pomyślał chwilę i powiedział: „Tego dnia w 1939 r. była mobilizacja. Wczesnym rankiem około godz. 5.00 zbudził mnie duży ruch panujący w Lesznie. Ulicą 17 Stycznia prowadzącą do koszar biegły drobne grupy żołnierzy z karabinami maszynowymi i działkami przeciwpancernymi. Naprzeciw żołnierze czekali z koń- 
rączkowych przygotowań do wojny: początkowo w Lesznie, a od 26 sierpnia z trasy wędrówki do odległej o ok. sto km od Leszna Słupcy, która zapoczątkowała jego trwającą ponad pięć lat wojenną tułaczkę. Dzień agresji Niemiec na Polskę, który spędził w Słupcy, opisywał następująco: „Piątek 1 września. Około godz. 9 tej plutonowy przyszedł z wiadomością jakoby wybuchła wojna. Przyjęliśmy ją z niedowierzaniem. Później byliśmy na spacerze w parku po powrocie było już pewnym, że jest wojna - nad Słupcą bardzo nisko krążyły jakieś samoloty - prawdopodobnie były to polskie. Wówczas rozpoczęło się przygotowanie piwnicy na podwórzu na schron. Przygotowywanie to polegało na obsypywaniu jej ziemią". Opisy kolejnych dni września 1939 r. przedstawiają exodus ludności cywilnej przemieszczającej się pieszo i na furmankach, ruchy wojsk polskich, bombardowania uciekających przez niemieckie samoloty oraz dalszą tułaczkę do wsi Krzyżanowice w pobliżu Kutna, gdzie niebawem miało dojść do krwawych walk nazwanych później bitwą nad Bzurą. Kolejny szkic zawarty w tym brulionie, napisany 15 października 1974 r., stanowi ciekawy materiał wspomnieniowy ukazujący zarazem rozbudzanie zainteresowania Wędzkiego zarówno historią, jak i krajoznawstwem połączonym z poznawaniem różnych kultur. W swoich przyszłych badaniach będzie on łączył razem wszystkie te dyscypliny, co doprowadzi do powstania wielu ważnych i ciekawych prac z zakresu osadnictwa i początków reformy miejskiej w Europie Środkowej. Cytowany poniżej jeden ze szkiców przedstawia krótkie migawki z życia w Krakowie i jego okolicach w pierwszych miesiącach okupacji, widziane oczami nastoletniego chłopca, który wraz z rodzicami znalazł tam schronienie u swojej cioci. Dlatego też przytoczę tutaj kilka migawek wchodzących w skład tego szkicu, rozdzielonych pomiędzy sobą niewielkimi odstępami: „I etap. Pobyt w Krakowie najpierw w grudniu krótko u Eli, potem w mieszkaniu przy ul. Mickiewicza 53. Lektura trylogii w zimie 1939/40 rozbudziła zainteresowania historią, a w tym i krajoznawcze. Wędrówki po Krakowie z [ciocią] Janką w poszukiwaniu żywności przyczyniły się do poznania miasta. Chyba wczesną wiosną, może w okolicy Wielkanocy duże wrażenie zrobiły fragmenty odkopanych tuż przed wojną murów miejskich przy plantach między Sienną a Gródkiem. W końcu 1939 lub na samym początku 1940 r. z Janką wieczorem poszliśmy na Stradom. Inne miasto o napisach hebrajskich, język, stroje, na rogach alei Dietla Żydówki sprzedające pieczony na małych piecykach bób. Dotarliśmy rejon Placu Wolnicy - kogoś szukaliśmy (kogo?)". Kolejna migawka zamieszczona w tym brulionie związana jest z relacją z opuszczenia Krakowa i przeprowadzki do rodziny w Miechowie, ponieważ z domów przy ul. Mickiewicza, przy której dotychczas mieszkał, Niemcy wysiedlali Polaków i na ich miejsce osiedlali

mi na oficerów, na płaskim dachu pobliskiego domu przy ul. Lipowej ustawiono karabin ckm". Podobnej treści wspomnienie znalazłem na luźnej kartce w brulionie. 
swoich przybyłych z Rzeszy urzędników. „W maju na Zielona Święta 1940 r. wyjazd z tatą do Miechowa. Za kopcem czekał Wicek z końmi - przejazd do Pstroszyc. Było około 15 maja (!) - płaty zrudziałego śniegu leżały w zagłębieniach zboczy północnych. Ni śladu zieleni". Dalsze migawki zawierają opisy okolic Miechowa z podkreśleniem tajemniczości otaczającej pagórkowate krajobrazy okolicznych wsi i opowieści o skarbach zasłyszane od ich mieszkańców. W kolejnych szkicach znajdują się ciekawe informacje o rodzących się w latach wojny jego pasjach i zainteresowaniach, które $\mathrm{z}$ biegiem czasu miały zaowocować bogatym dorobkiem naukowym, w nim zaś widać duży nacisk na interdyscyplinarne postrzeganie zjawisk społecznych zachodzących na przestrzeni dziejów. Warto zatem spojrzeć na jeszcze jeden własnoręcznie po latach sporządzony szkic, w którym przedstawiona przez niego geneza wczesnych zainteresowań kolekcjonerskich splata się z potrzebą badania przeszłości. Wszystko to jednak rozgrywało się na tle wydarzeń drugiej wojny światowej, pomimo których Wędzki próbował w miarę możliwości realizować i rozwijać swoje młodzieńcze marzenia, znajdujące swój wyraz zarówno w kolekcjonerstwie, jak i licznych wędrówkach po okolicy, oraz w gromadzeniu i spisywaniu informacji na temat jej przeszłości, co po siedemdziesięciu latach zaowocowało wydaniem monografii ${ }^{7}$. Treść tego szkicu jest następująca: „Bakcyla kolekcjonerskiego rozbudziła mama. Zbierała dla mnie znaczki pocztowe, kartki i gdy miałem 7 lat nauczyła mnie wklejać je do zeszytu. Niewątpliwie duży wpływ na mnie miał wuj Stanisław Królikowski filatelista, zbieracz pamiątek legionowych. Bakcyl chwycił i do wybuchu wojny miałem niewielki zbiór filatelistyczny. Album został na przechowaniu w Lesznie. Wyjechałem z odklejonymi najcenniejszymi znaczkami, które utraciłem w Łodzi w 1939 r. W Krakowie w latach 1940-41 zdobyłem sporo znaczków. Jednocześnie pod wpływem Trylogii i zabytków Krakowa coraz silniejsze zainteresowania historią. Po przeniesieniu w lecie 1941 do Miechowa spotęgowanie tych zainteresowań poprzez legendy o Jaksie, bitwie 1863. W lecie 1941 marzenia o stworzeniu własnego muzeum typu XIX-wiecznego zbioru starożytności. Możliwości niewielkie: namulit znaleziony na Widnicy, strzałki pionowe, kamień wapienny z odciskiem. Pierwsze monety (przed 1939 miałem kilka zagranicznych: włoską z ok. 1910 r. francuską, niemiecką)". Chcąc uzupełnić powyższy szkic własnym komentarzem, należy dodać, że ów „bakcyl kolekcjonerski" w kolejnych latach rozkwitł i w pełni zawładnął życiem Wędzkiego. Wyrazem jego były: stworzona przez niego pokaźna kolekcja

7 A. Wędzki, Miechów w średniowieczu. Studia z dziejów miasta i klasztoru. Zagadka Jaksy, Warszawa 2014. Praca ta była ostatnią monografią napisaną przez Wędzkiego i wydana na trzy lata przed śmiercią. Z jego ustnej relacji dowiedziałem się, że zamiar jej napisania podjął jeszcze w czasie wojenne tułaczki, mieszkając w Miechowie. Stanowi ona zarazem klamrę spinającą początki jego zainteresowań przeszłością związane z Miechowem oraz powrót do nich u schyłku życia. 
znaczków, wiele tysięcy zgromadzonych cennych monet i banknotów, które - jak wspomniałam - zgodnie z jego ostatnią wolą zostały przekazane Bibliotece Kórnickiej, liczne fragmenty ceramiki z czasów przedhistorycznych i wczesnośredniowiecznych, spośród których 86 przekazał za życia Muzeum Archeologicznemu w Poznaniu, liczący ok. dziesięć tys. egzemplarzy księgozbiór przekazany Instytutowi Slawistyki PAN, wraz z bogatą kolekcją map sztabowych i planów miast z XIX i XX w., a także liczące kilka metrów, wstępnie uporządkowane materiały naukowe, genealogiczne, związane zarówno z jego rodziną, jak i rodziną Niesiołowskich, z której pochodziła jego małżonka Anna Niesiołowska-Wędzka ${ }^{8}$.

Jak już wspomniałem, o ile informacje zawarte $\mathrm{w}$ omówionym przeze mnie powyżej brulionie bezpośrednio związane są z osobą Wędzkiego, o tyle w drugim z brulionów przeważają opisy biograficzne różnych osób oraz uzyskane za pomocą ustnych relacji informacje o przodkach Wędzkiego zarówno ze strony matki, jak i ojca, żyjących od początku XIX w., aż do czasów nam współczesnych. Spośród kilkudziesięciu opisów znajdujących się w tym brulionie szczególne zainteresowanie wzbudzają zwłaszcza te, które przedstawiając pewne pojedyncze wydarzenia z życia antenatów Wędzkiego, rzucają zarazem światło na obyczaje panujące na przełomie XIX i XX w. w owej małej społeczności, w której przyszło im żyć. W pierwszym z nich, zatytułowanym Tradycja ustna, Wędzki opisuje na kilku stronach historię swojego pradziada Macieja, który - jak podaje - umarł w 1908 r. w wieku ok. 67 lat. Składa się ona z kilku zdań stanowiących jakby odrębne informacje, opatrzone nawiasami zawierającymi inicjały i daty, z których można się domyślać, że chodzi tutaj o imiona lub nazwiska osób, będących informatorami. Nie wiadomo dokładnie, o jakie osoby tutaj chodzi. Można się domyślać, że litery M[ama] i T[ata] oznaczają jego rodziców, natomiast trudno stwierdzić, kogo oznacza literka "I" - być może stanowi ona symbol informacji uzyskanej od osoby dobrze zorientowanej w genealogii rodzinnej, być może chodziło tutaj o podkreślenie, że jest to ustnie uzyskana informacja, niemająca potwierdzenia w znanych materiałach znajdujących się w źródłach pisanych. Również zapisane obok inicjałów daty zasłyszanych informacji, takie jak 24 grudnia, wskazują, że informatorem musiała być bliska mu osoba, która snuła rodzinne wspomnienia zapewne przy stole wigilijnym. Jako przykład przytoczę dwa fragmenty. Pierwszy dotyczy opisu życia wspomnianego pradziada Macieja. „Zgodnie wspomina się, że mieszkał na Starej Wsi koło szkoły, podobno w kurnej chacie. Miał tam 2 morgi łąki (I. 23.XII.56). Miał nogę sztywną, podobno prze-

${ }^{8}$ Ceramika została zebrana głównie w okolicach Leszna i Kościana w trakcie badań powierzchniowych prowadzonych w trakcie pieszych wędrówek w latach 1951-1955, o czym informuje znajdujący się w jego spuściźnie szczegółowy spis znalezisk wraz z datami i miejscami znalezienia poszczególnych artefaktów. 
strzeloną. W domu o tym mało się mówiło. Czasem prababka mu wypominała: po coś tam lazł? (I. 24.XII.56, 21.VIII.60). Prawdopodobnie nastąpiło to w czasie powstania styczniowego. Jako kaleka nie mógł prowadzić gospodarstwa, robił kosze, półkoszki z wikliny, bryczki dla okolicznych dworów. Skupywał wiklinę. Dorobił się na tym i rozszerzył gospodarstwo. Prababka miała pudełko złotych monet, po jej nagłej śmierci podobno nie odnaleziono go (I. 21.VIII.60)". Kolejny fragment dotyczy zwyczajów ludności wiejskiej z okolic Miechowa związanych z odpustami. „Na początku XX w. proboszcz miechowski organizował wyjazdy końmi na odpust do Kalwarii. Proboszcz załatwiał formalności graniczne ${ }^{9}$. Wyprawa trwała tydzień. Dłużej trwały odpusty do Częstochowy, które prowadziły okrężną drogą przez Gidle. Zamawiali po drodze msze w niektórych parafiach. Wyjazd poprzedzały długie przygotowania żywności (sery suszone, wędliny). Bliższe pielgrzymki urządzano do Zielenic. Z odpustów przywożono dla dzieci gościńce np. różańce z pierników. Powitanie powracających z Częstochowy odbywało się powyżej krzyża na Cichej. Dziadkowie jeździli - pradziad ze względu na sztywną nogę na wozie. Część drogi zdrowi szli pieszo. Duże przeżycie”. Można zauważyć, że notatki sporządzone przez Wędzkiego z zasłyszanych przez niego ustnych relacji stanowią nie tylko bogate źródło do badania losów poszczególnych rodzin na przestrzeni XIX i XX w., ale także ciekawy materiał dla badającego dzieje i obyczajowość szerszych grup społecznych żyjących $w$ tym okresie na ziemiach polskich. Uzupełnieniem informacji przekazanych w formie notatek są liczne opisane na odwrocie rodzinne fotografie oraz liczne oryginały dokumentów, m.in. zezwolenie wydane 26 marca 1917 r. na prowadzenie przez ciotkę Wędzkiego panią Marię Kowalczyk trafiki tytoniowej w Krakowie przy ul. Karmelickiej 39, dokument wystawiony 1 marca 1910 r. przez Magistrat stoł. król. Miasta Krakowa zawiadamiający o wpisaniu Marii Kowalczyk wraz $\mathrm{z}$ rodziną do ksiąg tutejszej ludności, wreszcie - zachowana w dobrym stanie legitymacja z 1 kwietnia 1915 r., zezwalająca tejże pani na pozostanie w twierdzy Kraków w razie ewakuacji przed nadciągającymi wojskami rosyjskimi. Biografię Marii Kowalczyk uzupełniają liczne świadectwa, w tym świadectwo ukończenia przez nią kursu Praktycznych Robót Kobiecych przy szkole Wydziałowej Żeńskiej w Krakowie. Jest ono sporządzone w formie książeczki w twardej okładce, na szczególną uwagę zasługuje niezbyt udolnie w kilku miejscach poprawiona data tego kursu, który rzekomo miał miejsce od 18 lutego 1894 r. do 30 stycznia1895 r. Kto i w jakim celu dokonał sfałszowania tego dokumentu? Tego zapewne nigdy się nie dowiemy. Materiały związa-

\footnotetext{
${ }^{9}$ Najprawdopodobniej były to pielgrzymki do leżącej w pobliżu Wadowic Kalwarii Zebrzydowskiej. Chcąc do niej dotrzeć z okolic Miechowa, trzeba było na początku XX w. przekraczać granicę, ponieważ Miechów leżał w zaborze rosyjskim, a Kalwaria Zebrzydowska znajdowała się w należącej do Austrii Galicji.
} 
ne z osobą Marii Kowalczyk nie tylko dokumentują jej życiowe losy, ale także stanowią bogate źródło wiedzy dla badaczy zainteresowanych społeczną rolą kobiety w społeczeństwie Krakowa na przełomie XIX i XX w. Podobnych teczek zawierających rodzinne dokumenty wraz ze zdjęciami i załączonymi biografiami napisanymi ręką Wędzkiego znajdziemy więcej. Dotyczą one najbliższych mu osób, takich jak: rodzice, żona, ciocie, a także dalszych, należących do rodziny żony, w tym zwłaszcza zmarłego w oflagu pod koniec drugiej wojny światowej jej ojca Andrzeja Niesiołowskiego, którego bogatą, uporządkowaną przez siebie i opisaną spuściznę przekazał Wędzki do poznańskiego Oddziału Archiwum PAN. Na jej podstawie została wydana monografia Andrzeja Niesiołowskiego, będącego przed wojną jednym z najwybitniejszych polskich badaczy w dziedzinie pedagogiki i psychologii ${ }^{10}$. Można stwierdzić, że materiały biograficzne poszczególnych członków rodziny Wędzkiego oraz jego żony, zamieszczone przez Profesora w oddzielnych teczkach dla każdej z osób, stanowią cenną część jego spuścizny ukazującą poza dziejami poszczególnych osób także strukturę polskiego społeczeństwa oraz jego losy w okresie od schyłku XIX w. do końca drugiej wojny światowej. Jest to zarazem szeroki materiał do analizy dla przyszłych badaczy tego okresu.

Kolejnym fragmentem omawianej spuścizny, na który warto zwrócić uwagę, jest przekazany poznańskiemu Oddziałowi Archiwum PAN przez Wędzkiego pod koniec jego życia zbiór fotografii noszący tytuł Archiwum fotograficzne. Składa się on z dziewięciu pudeł, zawierających ok. dziesięć tys. wykonanych własnoręcznie czarno-białych fotografii o formacie $6 \times 9$, lub $10 \times 15$ $\mathrm{cm}$, powstałych $\mathrm{w}$ okresie od lat pięćdziesiątych do końca lat siedemdziesiątych XX w. Każda $\mathrm{z}$ fotografii została naklejona na tekturową kartkę i opisana wraz z podaniem miejsca zamieszczonego na zdjęciu obiektu oraz daty jej wykonania, a następnie ułożona w kolejności we właściwym miejscu w systemie alfabetycznym. Przedstawione są na nich niemal wyłącznie zabytkowe budowle i założenia urbanistyczne, takie jak rynki czy place z różnych okresów historycznych, zarówno z terenu Polski, jak i innych krajów Europy Środkowo-Wschodniej. Trudno jest obecnie ocenić przydatność tego typu dokumentacji do badań naukowych, jednak nie umniejsza to w żadnym stopniu wysiłku włożonego w powstanie tej kolekcji. Jest ona także świadectwem potrzeby dokumentowania oglądanych zabytkowych budowli oraz dokumentowania i utrwalenia w kadrze ulotności chwili w przeświadczeniu, że niektóre spośród obiektów, znajdujących się wówczas w złym stanie technicznym, a niebędących według ówcześnie obowiązujących przepisów zabytkami, zostanie niebawem zburzonych, natomiast zrobione zdjęcie stanowić będzie kiedyś jedyny ślad ich istnienia. Przykładem może być zrobiona w latach sie-

${ }^{10}$ J. Kostkiewicz, Andrzej Niesiołowski. Zarys pedagogiki ogólnej. Rękopisy z oflagu, Kraków 2017. 
demdziesiątych $X X$ w. fotografia stojącego na rozstajach dróg w Koninie, chylącego się ku upadkowi budynku osiemnastowiecznej karczmy, po której dzisiaj nie pozostał już żaden ślad.

Zapewne podobną rolę, jak fotografie, miały odegrać w zamierzeniu Wędzkiego tzw. Szkice krajoznawcze. Taki tytuł nosiły odręcznie sporządzone opisy tras wycieczek zarówno tych krótkich na obrzeża Leszna czy Poznania, jak i wielodniowych wypraw w różne części Polski, później Europy. Opisane są w nich: trasy wędrówek, ukształtowanie mijanego terenu, a zwłaszcza leżące przy nim zabytkowe obiekty wraz z ich historią, obecnym wówczas stanem ich zachowania i otaczającą je roślinnością, szczególnie w odniesieniu do pozostałości podworskich, założeń parkowych czy cmentarzy otaczających stare kościoły. Z opisów tych możemy także dowiedzieć się o zniszczeniach poszczególnych miast w wyniku drugiej wojny światowej i postępującej $w$ pierwszych latach po jej zakończeniu odbudowie. $\mathrm{O}$ ile na wykonanych przez niego zdjęciach niekiedy przypadkowo występują uwiecznione w kadrze osoby, o tyle w Szkicach krajoznawczych nie ma jakichkolwiek wzmianek o ludziach zamieszkujących odwiedzane tereny bądź o wznoszonych po wojnie nowych budowlach o charakterystycznej dla tamtego okresu architekturze. Brak wzmianek o ludziach żyjących na odwiedzanych i wzmiankowanych $\mathrm{w}$ opisach terenach stanowi dużą stratę, ponieważ wiele opisów pochodzących z lat 1947-1950 odnosi się do przyznanego Polsce po drugiej wojnie światowej Dolnego Śląska, zwłaszcza do okolic Wałbrzycha. Rejon Wałbrzycha w pierwszych latach powojennych stanowił swoisty tygiel narodowościowy, w którym mieszała się napływowa ludność z dawnych wschodnich terenów II Rzeczypospolitej z niewysiedloną jeszcze ludnością niemiecką zatrudnianą m.in. w kopalniach, a także ściągającą na te tereny ocalałą po holokauście ludnością żydowską, która po kilku latach wyjechała do nowo powstającego państwa Izrael. Niemniej jednak Szkice krajoznawcze stanowią wartościowy materiał opisujący postrzeganie zmieniającego się świata widzianego początkowo oczami młodego studenta, a dalej stopniowo coraz dojrzalszego badacza dziejów. Zawarte są one w szesnastu ponumerowanych zeszytach. Każdy ze Szkiców opatrzony został dokładną datą. Obejmują one opisy kilku tysięcy wędrówek z lat 1947-2015, czyli z okresu niemal sześćdziesięciu lat.

Omówione przeze mnie fragmenty materiałów wchodzących w skład spuścizny Wędzkiego, chociaż w dużym stopniu nie są bezpośrednio związane z jego działalnością naukową, na którą składają się liczne prace, zarówno te opublikowane, jak i nadal znajdujące się w maszynopisie, stanowią ciekawe pole do badań dla przedstawicieli różnych kierunków wchodzących w skład nauk pomocniczych historii, a także ukazują bogaty i różnorodny obraz świata widziany oczami ich twórcy. Obraz ten kształtowała trwająca od najmłodszych lat aż do schyłku życia pasja zbierania i kolekcjonowania. Odnosiła się ona zarówno do przedmiotów związanych z przeszłością, takich jak znacz- 
ki, książki, mapy czy monety, jak też do gromadzenia wiedzy o przeszłości i uchronienia jej w ten sposób przed ludzką niepamięcią. Przejawem jej były skrupulatnie gromadzone materiały genealogiczne obrazujące kilka pokoleń zarówno ze strony Wędzkiego, jak i jego żony, opisy tras wędrówek czy kolekcja zdjęć składająca się na Archiwum fotograficzne. Spuścizna ta stanowi bogate źródło poszerzające naszą wiedzę, ale zarazem w miarę stopniowego zagłębiania się w nią rodzi się wiele nowych pytań, na które, niestety, nie uzyskamy już odpowiedzi. Nie znajdziemy w badanej spuściźnie choćby odpowiedzi na pytanie co do motywów, jakie sprawiły, że postrzeganie przez jej twórcę otaczającego go świata ograniczało się niemal wyłącznie do przeszłości związanej z działalnością materialną żyjących niegdyś ludzi, przy uderzającym braku zainteresowania otaczającą współczesnością w postaci rozgrywających się na jego oczach codziennych ludzkich dramatów. Pomimo braku odpowiedzi na wiele pytań, spuścizna ta stanowi tworzone systematycznie przez lata bogate źródło, służące do poznania ciągłości losów przedstawicieli kilku pokoleń Polaków żyjących na przestrzeni ostatnich 150 lat, wywodzących się z różnych środowisk, funkcjonujących w dwóch zaborach, którzy po odzyskaniu przez Polskę niepodległości w 1918 r. wyruszyli na teren dawnego zaboru pruskiego, aby tam od podstaw tworzyć polskie szkolnictwo. Dopełnieniem jej są losy kolejnego pokolenia, urodzonego już w niepodległej Polsce, któremu dane było doświadczyć okropności drugiej wojny światowej i wchodzenia w dojrzałe życie, związane z początkami działalności naukowej, w epoce stalinowskiej. Z tym okresem związana jest mało znana, lecz ciekawa dzięki pozostawionej spuściźnie biografia poznańskiego badacza dziejów wczesnej Słowiańszczyzny i osadnictwa na terenach Europy Środkowej, redaktora Słownika starożytności słowiańskich - prof. Andrzeja Wędzkiego.

\section{Bibliografia}

\section{Źródła archiwalne}

Archiwum Polskiej Akademii Nauk w Warszawie Oddział w Poznaniu, Spuścizna prof. Andrzeja Wędzkiego, bez sygn.

\section{Opracowania}

Grzesik R., Profesor Andrzej Wędzki jako archeolog i slawista w 80-lecie urodzin, "Slavia Antiqua” 2007, t. 48, s. 285-316.

Grzesik R., Profesor Andrzej Wędzki jako badacz Ziemi Konińskiej, „Rocznik Koniński” 2007, t. 16, s. 347-350.

Kostkiewicz J., Andrzej Niesiołowski. Zarys pedagogiki ogólnej. Rękopisy z oflagu, Kraków 2017.

Stownik starożytności stowińskich. Encyklopedyczny zarys kultury Stowian od czasów najdawniejszych, t. 1-8, pod red. A. Gąsiorowskiego, W. Kowalenki, G. Labudy, T. Lehr-Spławińskiego, A. Wędzkiego, Wrocław 1961-1996.

Wędzki A., Miechów w średniowieczu. Studia z dziejów miasta i klasztoru. Zagadka Jaksy, Warszawa 2014.

Wędzki A., Przechadzki po Wielkopolsce, Poznań 2007. 
Wojciech Mądry

\title{
Spuścizna jako źródło do badań nad biografią i działalnością na- ukową historyka - badacza dziejów Słowiańszczyzny Andrzeja Wędzkiego (1927-2017)
}

\begin{abstract}
Streszczenie
W niniejszym artykule przedstawiona jest postać poznańskiego profesora, historyka, badacza dziejów osadnictwa słowiańskiego na terenach Europy Środkowej, redaktora Stownika starożytności stowiańskich - Andrzeja Wędzkiego (1927-2017).Widziany jest on poprzez pryzmat bogatej i ciekawej spuścizny, którą jeszcze za życia przygotowywał z myślą o przekazaniu jej takim instytucjom badawczym, jak Biblioteka Kórnicka czy Archiwum PAN. Przedstawiony powyżej fragment tej spuścizny wskazuje na zamiłowania Wędzkiego do kolekcjonowania i na odczuwaną potrzebę utrwalania w postaci opisów czy fotografii owej „ulotnej chwili”, na którą składają się: rodzinne relacje, wspomnienia, zapiski z wojennej tułaczki, podróży czy tablice genealogiczne przodków własnych i współmałżonki. Są one ważnym i ciekawym źródłem dla badacza szukającego informacji zarówno na temat jego osoby, jak również dziejów społeczeństwa polskiego na przestrzeni ostatnich 150 lat.
\end{abstract}

Słowa kluczowe: archiwum, badacz, biografia, historia, kolekcjonerstwo, spuścizna, Wędzki Andrzej

\section{Heritage as a source for examining the life and academic activity of Andrzej Wędzki (1927-2017), a historian and researcher of the history of Slavdom}

\begin{abstract}
In the following article, we present the character of Andrzej Wędzki (1927-2017) - a Poznańbased professor, historian, and researcher of the history of Slavic settlements in the area of Central Europe, the editor of the Dictionary of Slavonic Antiquities (Stownik starożytności stowiańskich). Andrzej Wędzki is presented with regard to his very rich and interesting heritage which he himself had meant to will to scientific research institutes, such as the Library of Kórnik or the Archive of the Polish Academy of Sciences. The piece of his heritage that we presented above shows his great passion for collecting as well as preserving - by means of descriptions or photography - all those "elusive moments" such as family relations; memories; notes from the war, exile, or his travels; genealogical charts of his own ancestors or those of his wife. They are an essential, and at the same time very interesting, source for everyone willing to conduct research into the life of Andrzej Wędzki and the history of the Polish society in the last 150 years.
\end{abstract}

Key words: archive, researcher, research, biography, history, collecting, heritage, Andrzej Wędzki 